\title{
Effect of the Presence of Iodide on the Electron Injection Dynamics of Dye-Sensitized $\mathrm{TiO}_{2}$-Based Solar Cells
}

\author{
Amanda L. Smeigh, ${ }^{\dagger}$ Jordan E. Katz, ${ }^{\ddagger}$ Bruce S. Brunschwig, ${ }^{*,+, \S}$ Nathan S. Lewis, ${ }^{*, *}$ and \\ James K. McCusker*, \\ Contribution from the Department of Chemistry, Michigan State University, East Lansing, Michigan 48824, and the \\ Division of Chemistry and Chemical Engineering, Kavli Nanoscience Institute, and the Molecular Materials \\ Research Center of the Beckman Institute, California Institute of Technology, Pasadena, California 91125
}

Received: April 18, 2008; Revised Manuscript Received: June 30, 2008

\begin{abstract}
The electron injection dynamics of dye-sensitized $\mathrm{TiO}_{2}$-based solar cells have been investigated to determine the effects of replacing the $\mathrm{I}_{3}{ }^{-} / \mathrm{I}^{-}$redox system by non-redox-active supporting electrolytes. $\mathrm{TiO}_{2}$ films were sensitized with $\mathrm{Ru}(\mathrm{dcbpy})_{2}(\mathrm{NCS})_{2}$, where dcbpy $=4,4^{\prime}$-dicarboxylic acid-2,2'-bipyridine (the "N3" dye), and placed in contact with either $\mathrm{M}\left(\mathrm{ClO}_{4}\right)$ or $\mathrm{M}\left(\mathrm{I}_{3}{ }^{-} / \mathrm{I}^{-}\right)$solutions $\left(\mathrm{M}=\mathrm{Li}^{+}\right.$or $\left.\left(\mathrm{n}-\mathrm{C}_{4} \mathrm{H}_{9}\right)_{4} \mathrm{~N}^{+}\right)$; cells that contained $\mathrm{I}_{3}{ }^{-} / \mathrm{I}^{-}$were fully functional solar cells whose steady-state photocurrents were directly measured. In $\left(\mathrm{n}-\mathrm{C}_{4} \mathrm{H}_{9}\right)_{4} \mathrm{~N}^{+}-$ containing solutions, significant differences were observed between the measured kinetics when $\mathrm{ClO}_{4}{ }^{-}$was replaced by the redox-active $\mathrm{I}_{3}{ }^{-} / \mathrm{I}^{-}$system. In particular, a ps time scale loss of the metal-to-ligand chargetransfer excited-state of the $\mathrm{N} 3$ dye, associated with electron injection, that was observed in cells containing either $\mathrm{LiClO}_{4}$ or $\left[\left(\mathrm{n}-\mathrm{C}_{4} \mathrm{H}_{9}\right)_{4} \mathrm{~N}\right] \mathrm{ClO}_{4}$ was absent in fully functional solar cells that contained $\left[\left(\mathrm{n}-\mathrm{C}_{4} \mathrm{H}_{9}\right)_{4} \mathrm{~N}\right] \mathrm{I} / \mathrm{I}_{2}$. These results underscore the importance of performing kinetics measurements on this class of solar cells under operational conditions if one is to obtain reliable correlations between the dynamics data and the steadystate performance metrics of the solar cell devices.
\end{abstract}

\section{Introduction}

The 1991 report by O'Regan and Grätzel of a regenerative solar cell based on $\mathrm{TiO}_{2}$ nanoparticles ${ }^{1}$ has spawned tremendous interest in the development of photovoltaic devices based on the concept of dye sensitization. In this process, the primary light-absorbing entity is a molecule covalently attached or otherwise adsorbed to the surface of a wide band gap semiconductor. Photon capture by the molecule results in the formation of an excited-state whose energetics are such that electron transfer into the conduction band of the semiconductor is thermodynamically favorable. When configured in a closedcircuit assembly, photocurrents exceeding $20 \mathrm{~mA} \mathrm{~cm}{ }^{-2}$ and overall energy conversion efficiencies of $\sim 11 \%$ have been achieved under simulated solar illumination. ${ }^{2}$ The projected low cost associated with fabrication of these devices, coupled with their environmentally benign nature, has provided motivation to improve the overall efficiencies of these devices.

A variety of factors must be optimized to maximize the performance characteristics of these cells, including the absorption cross-section of the sensitizer, the kinetics of electron transport, and the redox species that performs the reduction of the oxidized form of the chromophore. ${ }^{3-5}$ The first step in the sequence of events following light absorption is interfacial

* To whom correspondence should be addressed. E-mail: bsb@caltech.edu, nslewis@caltech.edu,jkm@chemistry.msu.edu.

$\dagger$ Michigan State University.

$¥$ Division of Chemistry and Chemical Engineering, California Institute of Technology.

$\S$ Molecular Materials Research Center, The Beckman Institute, California Institute of Technology. electron-transfer from the chromophore into the semiconductor material. Injection into the conduction band occurs on time scales ranging from $10^{-13}$ to $>10^{-10} \mathrm{~s}$ and involves both thermalized and nonthermalized excited states of the chromophore. ${ }^{6-14}$ Internal quantum yields approaching unity can be achieved provided that the lifetimes for injection and electron collection are significantly shorter than those for the injecting state and back-electron transfer. A detailed understanding of the interfacial electron-transfer step thus provides important information concerning a key performance characteristic of this class of photovoltaics.

Time-resolved spectroscopic measurements are most often performed on sensitized $\mathrm{TiO}_{2}$ films that are either dry ${ }^{6,9,11,12}$ or in contact with solutions that contain supporting electrolytes that are similar, but not identical, to that used in the functional cell. ${ }^{7,8,10-12}$ Specifically, the redox-active component of the electrolytic mixture, typically a combination of an $\mathrm{I}^{-}$salt and $\mathrm{I}_{2}$, is commonly excluded in time-resolved spectroscopic studies due to the optically opaque nature of the combination of these species. The absence of these redox components clearly prohibits regeneration of the cell in a manner similar to that under steadystate conditions; however, the effect of this change on other aspects of cell performance is not well elucidated. In this report, we show that substituting an $\mathrm{I}^{-}$salt for its $\mathrm{ClO}_{4}{ }^{-}$analog can result in a profound change in the dynamics associated with electron injection in certain electrolyte solutions, thereby raising concerns as to the relevance of using kinetics data obtained under conditions that do not match the operational conditions of the cell to interpret the performance characteristics of this class of $\mathrm{TiO}_{2}$-based photovoltaics. 


\section{Experimental Section}

All materials were purchased from commercial sources and unless otherwise noted were used without further purification. $\mathrm{TiO}_{2}$ nanoparticles in the form of a screen-printable paste (Tinanoxide HTSP) and Ru(dcbpy $)_{2}(\mathrm{NCS})_{2}$ (the "N3" dye, where dcbpy is 4,4'-dicarboxylic acid-2,2'-bipyridine) were purchased from Solaronix. Nanoparticles of $\mathrm{ZrO}_{2}$ were synthesized by sol-gel methods. Lithium perchlorate was dried by fusing at $240{ }^{\circ} \mathrm{C}$ under vacuum. Tetra(n-butyl)ammonium perchlorate was recrystallized from hot ethanol with diethylether and was dried under vacuum at $130{ }^{\circ} \mathrm{C}$. Tetra(n-butyl)ammonium iodide was recrystallized from acetone by addition of ether and was dried under vacuum at room temperature. Iodine was sublimed at $40{ }^{\circ} \mathrm{C}$.

A. Sample Preparation. A "sandwich-cell" configuration, consisting of a dye-sensitized film, a silicone rubber spacer, and a glass cover slide, was used to study the injection dynamics. ${ }^{15}$ To prepare the $\mathrm{TiO}_{2}$-based cells, $\mathrm{TiO}_{2}$ films on F-doped $\mathrm{SnO}_{2}-$ coated glass were placed in contact with a $0.2 \mathrm{M} \mathrm{TiCl}_{4}$ solution for at least $8 \mathrm{~h}$. The films were rinsed and then sintered at 450 ${ }^{\circ} \mathrm{C}$ for $30 \mathrm{~min}$ under flowing air. The films were then cooled to $120^{\circ} \mathrm{C}$, and immediately placed in an ethanolic solution of the $\mathrm{N} 3$ dye for $\sim 12 \mathrm{~h}$. The sensitized films were rinsed with $\mathrm{C}_{2} \mathrm{H}_{5} \mathrm{OH}$ and were then combined in the sandwich cell with the desired electrolyte solution in an Ar atmosphere. Assembled cells were kept in a light-proof container until they were needed for spectroscopic studies.

Films of the $\mathrm{N} 3$ dye adsorbed to $\mathrm{ZrO}_{2}$ were prepared in a similar manner except that treatment with a metal chloride solution was omitted. Due to the relatively low binding affinity of the $\mathrm{N} 3$ dye to $\mathrm{ZrO}_{2}$, the $\mathrm{ZrO}_{2}$ films were contacted with the dye solution for $>24 \mathrm{~h}$. Assembly of the sandwich cell was carried out in an Ar atmosphere, as for the $\mathrm{TiO}_{2}$-based cells. In both cases, the electrolyte solutions contained dry $\mathrm{CH}_{3} \mathrm{CN}$ and fused salts of the supporting electrolyte, with the entire cell assembled in an Ar atmosphere. ${ }^{15}$

B. Femtosecond Time-Resolved Spectroscopy. The femtosecond time-resolved absorption spectrometer used for these studies has been described previously. ${ }^{16}$ A sapphire-generated continuum (450-950 nm) was used as the probe source for all measurements. Single wavelength kinetics traces were obtained by selecting wavelengths from the continuum by use of $10 \mathrm{~nm}$ band-pass filters that were positioned after the sample. The films were excited at $530 \mathrm{~nm}$, which is near the maximum of the lowest energy ${ }^{1} \mathrm{~A}_{1} \rightarrow{ }^{1} \mathrm{MLCT}$ (metal-to-ligand charge transfer) absorption of $\mathrm{N} 3$ bound to $\mathrm{TiO}_{2}$ or $\mathrm{ZrO}_{2}$. The differences in binding affinity of the $\mathrm{N} 3$ chromophore to $\mathrm{ZrO}_{2}$ vs $\mathrm{TiO}_{2}$ produced optical densities of the N3-sensitized films at $530 \mathrm{~nm}$ of $0.7-0.9$ for $\mathrm{TiO}_{2}$ and $0.3-0.5$ for $\mathrm{ZrO}_{2}$. Estimation of $\Delta t=$ 0 at each probe wavelength was achieved utilizing pump scatter from a neat film (i.e., from a film that had no adsorbed dye but that was otherwise nominally identical) and/or from stimulated Raman scattering from the solvent. Data sets reported herein typically were the signal average of 10 scans; all measurements were carried out obtained at room temperature. Significant photobleaching of the films was observed at high excitation power densities. ${ }^{17}$ Consequently, the pump beam was attenuated with neutral density filters to yield pump energies on the order of $\sim 2 \mu \mathrm{J}$ with a beam diameter of $\sim 1 \mathrm{~mm}$ at the sample. Films were excited through the back contact (i.e., through the back side of the glass slide on which the film had been deposited), and the sample was translated after each full scan of the optical delay line. When these protocols were followed, absorption
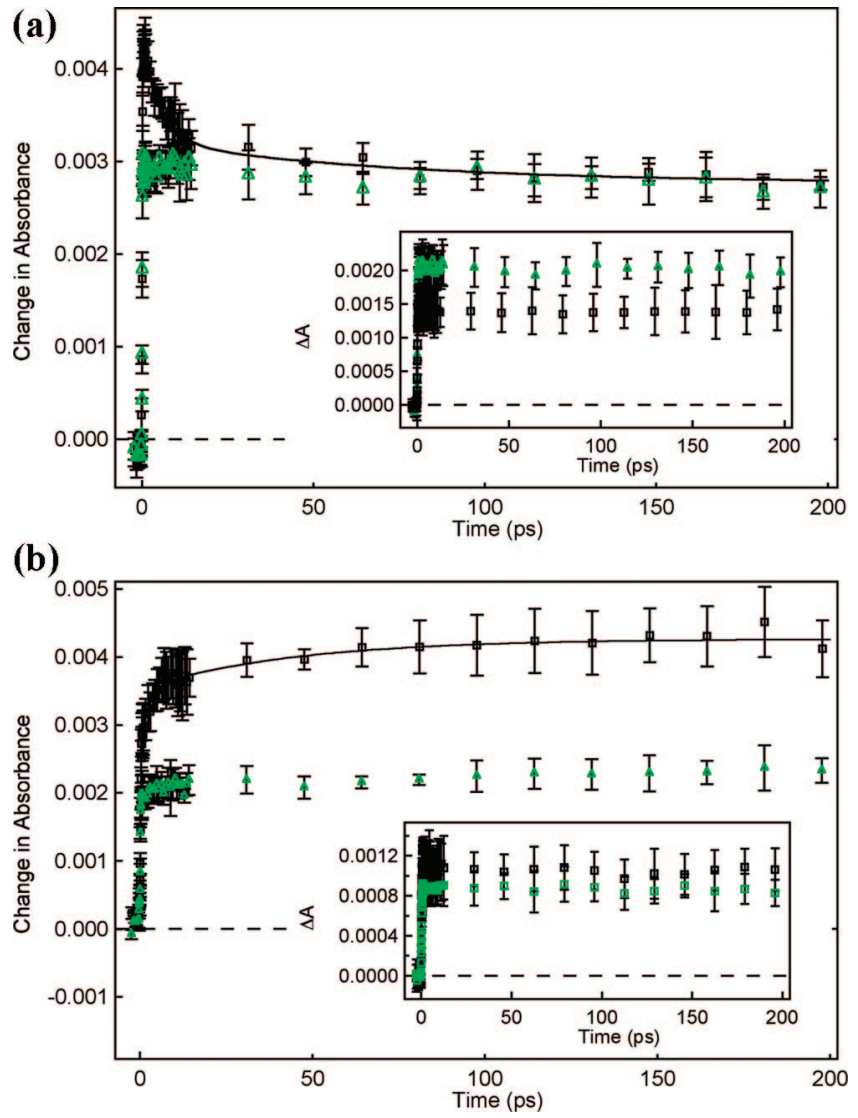

Figure 1. Time-resolved absorption data at $\lambda_{\text {probe }}=700 \mathrm{~nm}$ (a) and $\lambda_{\text {probe }}=800 \mathrm{~nm} \mathrm{(b)}$ for $\mathrm{TiO}_{2}$ films sensitized with the $\mathrm{N} 3$ chromophore in contact with $\mathrm{CH}_{3} \mathrm{CN}$ solutions containing $0.5 \mathrm{M}\left[\left(\mathrm{n}-\mathrm{C}_{4} \mathrm{H}_{9}\right)_{4} \mathrm{~N}\right]\left(\mathrm{ClO}_{4}\right)$ (black squares) and $0.5 \mathrm{M}\left[\left(\mathrm{n}^{-} \mathrm{C}_{4} \mathrm{H}_{9}\right)_{4} \mathrm{~N}\right] \mathrm{I} / 0.04 \mathrm{M} \mathrm{I}_{2}$ (green triangles) following $\sim 100 \mathrm{fs}$ excitation at $530 \mathrm{~nm}$; corresponding data acquired on $\mathrm{ZrO}_{2}$-based films are shown in the insets. The solid lines through the $\left[\left(\mathrm{n}-\mathrm{C}_{4} \mathrm{H}_{9}\right)_{4} \mathrm{~N}\right]\left(\mathrm{ClO}_{4}\right)$ data represent fits to exponential kinetic models. See text for further details.

spectra collected before and after all time-resolved measurements were essentially identical.

\section{Results and Discussion}

The absorption profiles of the excited-state of N3 (N3*) and of the oxidized form of the dye $\left(\mathrm{N}^{+}\right)$are similar throughout the visible region, making it difficult to find a spectral region in which both species do not contribute to the overall signal. At $700 \mathrm{~nm}, \mathrm{~N} 3 *$ has a larger molar absorptivity than ${ }^{*}{ }^{+}$, so data obtained at this wavelength preferentially reflect the temporal evolution of the excited-state of the sensitizer. The converse is true at $800 \mathrm{~nm}$. Data were collected at both of these probe wavelengths, following excitation into the lowest energy ${ }^{1} \mathrm{~A}_{1} \rightarrow{ }^{1}$ MLCT absorption of the chromophore. To further elucidate the dynamics associated with electron injection, timeresolved absorption data were acquired on $\mathrm{ZrO}_{2}$-based films, for which electron injection is not expected to occur because the conduction-band edge of $\mathrm{ZrO}_{2}$ lies above the energy of the N3 excited state. ${ }^{18}$

Figure 1 shows plots of time-resolved absorption data acquired on $\mathrm{ZrO}_{2}$ and $\mathrm{TiO}_{2}$ films in contact with solutions that contained either $\left[\left(\mathrm{n}-\mathrm{C}_{4} \mathrm{H}_{9}\right)_{4} \mathrm{~N}\right]\left(\mathrm{ClO}_{4}\right)$ or a mixture of $[(\mathrm{n}$ $\left.\left.\mathrm{C}_{4} \mathrm{H}_{9}\right)_{4} \mathrm{~N}\right] \mathrm{I}$ and $\mathrm{I}_{2}$. The latter electrolyte matches the conditions under which steady-state photocurrent measurements of N3sensitized $\mathrm{TiO}_{2}$-based solar cells have been obtained. ${ }^{15}$ The $\mathrm{ZrO}_{2}$ films (insets), in either electrolyte, exhibited a rapid rise in 
absorbance at both probe wavelengths, but exhibited no further changes within the temporal window of our experiment. This behavior is consistent with the formation, and subsequent persistence, of the ${ }^{3}$ MLCT excited-state of N3 under conditions in which no charge injection can occur. ${ }^{19}$

The $\mathrm{TiO}_{2}$-based films in the presence of $\left[\left(\mathrm{n}-\mathrm{C}_{4} \mathrm{H}_{9}\right)_{4} \mathrm{~N}\right]\left(\mathrm{ClO}_{4}\right)$ showed a similar pulse width-limited increase in differential absorbance at times near $\Delta t=0$. Because $\mathrm{N}^{+}$also absorbs at this probe wavelength, it is likely that a significant fraction of the initial observed absorption rise is associated with charge injection that cannot be resolved with the time resolution of our instrumentation. ${ }^{20}$ On longer time scales (i.e., $\Delta t>1 \mathrm{ps}$ ) at $\lambda_{\text {probe }}=700 \mathrm{~nm}$, a decrease in absorbance to a pseudo steadystate value was observed (Figure 1a). The absence of a similar decay feature for the $\mathrm{ZrO}_{2}$ films with $\mathrm{N} 3$ is strong evidence that the absorption dynamics for $\Delta t>1 \mathrm{ps}$ in this electrolyte can be ascribed to loss of $\mathrm{N} 3 *$ due to charge injection into the conduction band of $\mathrm{TiO}_{2}{ }^{21}$ This conclusion is further supported by the absorption increase observed for the N3-sensitized $\mathrm{TiO}_{2}$ films at $\lambda_{\text {probe }}=800 \mathrm{~nm}$ (Figure 1b), which is consistent with expectations for the formation of $\mathrm{N}^{+}$.

Analysis of the kinetics observed for N3-sensitized $\mathrm{TiO}_{2}$ in contact with $\left[\left(\mathrm{n}-\mathrm{C}_{4} \mathrm{H}_{9}\right)_{4} \mathrm{~N}\right]\left(\mathrm{ClO}_{4}\right)$ is not straightforward. A single exponential did not adequately represent the data, and the parameters corresponding to the biexponential fits shown in the figure were highly correlated. Modeling the data with various distribution functions (e.g., Williams-Watts) met with limited success. Issues associated with quantification of the injection dynamics in these cells will be elaborated upon in more detail separately. ${ }^{17}$ Nevertheless, the observations are broadly consistent with those reported by many other groups in terms of the presence of a picosecond time-scale injection process associated with this class of photovoltaics.

Dramatically different results were obtained when the electrolyte composition was altered to match that used in a functioning solar cell. For N3-sensitized $\mathrm{TiO}_{2}$ films in contact with $\left[\left(\mathrm{n}-\mathrm{C}_{4} \mathrm{H}_{9}\right)_{4} \mathrm{~N}\right] \mathrm{I} / \mathrm{I}_{2}$, the data at $\lambda_{\text {probe }}=700 \mathrm{~nm}$ (Figure 1a) were similar to those acquired on $\mathrm{ZrO}_{2}$ films with absorbed N3. Specifically, the picosecond time-scale kinetics process(es) evident in the $\mathrm{ClO}_{4}$-based electrolyte is completely absent in the presence of the $\mathrm{I}_{3}^{-} / \mathrm{I}^{-}$redox-active components. This conclusion is supported by the data at $\lambda_{\text {probe }}=800 \mathrm{~nm}$ (Figure 1b), where after the initial rapid absorbance increase following excitation $(\Delta t<1 \mathrm{ps})$, no significant variation in optical density was observed. Cells that contain $\left(n-\mathrm{C}_{4} \mathrm{H}_{9}\right)_{4} \mathrm{~N}^{+}$exhibit a photocurrent under steady-state irradiation, ${ }^{15}$ so electron injection is clearly occurring upon photoexcitation of this system. Hence, we suspect that most of this injection occurs in the time regime associated with the initial increase in absorption near $\Delta t=0$.

To ascertain whether the presence of $\mathrm{I}^{-}$or $\mathrm{I}_{2}$ was responsible for the difference in behavior relative to the $\mathrm{ClO}_{4}^{-}$-based solutions, data were acquired in the absence of $\mathrm{I}_{2}$ (Figure $\mathrm{S} 1$ and S2). The kinetics were qualitatively similar whether or not $\mathrm{I}_{2}$ was present, suggesting that the change from $\mathrm{ClO}_{4}{ }^{-}$to $\mathrm{I}^{-}$in the presence of $\left(\mathrm{n}-\mathrm{C}_{4} \mathrm{H}_{9}\right)_{4} \mathrm{~N}^{+}$was predominantly responsible for the difference in the observed kinetics.

Previous work from our laboratories ${ }^{15}$ has demonstrated a 5 -fold decrease in the short-circuit current density $\left(J_{\mathrm{sc}}\right)$ of devices that employed $\left[\left(\mathrm{n}-\mathrm{C}_{4} \mathrm{H}_{9}\right)_{4} \mathrm{~N}\right] \mathrm{I} / \mathrm{I}_{2}$ rather than $\mathrm{LiI} / \mathrm{I}_{2} / \mathrm{CH}_{3} \mathrm{CO}_{2} \mathrm{H}$ as the electrolyte. ${ }^{22} \mathrm{An}$ analogous set of experiments was therefore carried out using $\mathrm{Li}^{+} / \mathrm{CH}_{3} \mathrm{CO}_{2} \mathrm{H}$-based media. Similar kinetics were observed in the $\left[\left(\mathrm{n}-\mathrm{C}_{4} \mathrm{H}_{9}\right)_{4} \mathrm{~N}\right] \mathrm{ClO}_{4}$ and $\mathrm{LiClO}_{4}$ electrolytes, furthermore, the data acquired for $\mathrm{LiClO}_{4}$ vs $\mathrm{LiI} / \mathrm{I}_{2}$ were the same, within experimental error (Figure 2). This result is
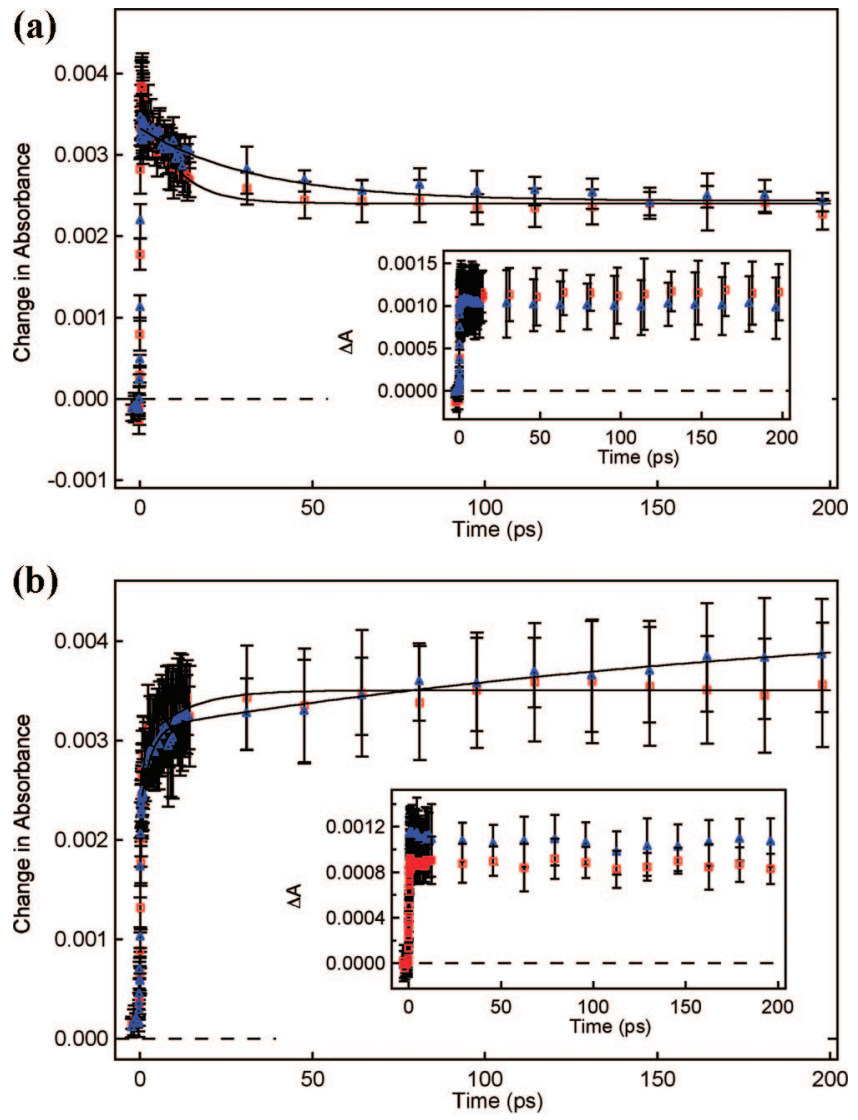

Figure 2. Time-resolved absorption data at $\lambda_{\text {probe }}=700 \mathrm{~nm}$ (a) and $\lambda_{\text {probe }}=800 \mathrm{~nm}$ (b) for $\mathrm{TiO}_{2}$ films sensitized with the $\mathrm{N} 3$ chromophore in contact with $\mathrm{CH}_{3} \mathrm{CN}$ solutions containing $0.5 \mathrm{M} \mathrm{LiClO}_{4} / 0.05 \mathrm{M}$ $\mathrm{CH}_{3} \mathrm{CO}_{2} \mathrm{H}$ (red squares) and $0.5 \mathrm{M} \mathrm{LiI} / 0.05 \mathrm{M} \mathrm{CH}_{3} \mathrm{CO}_{2} \mathrm{H} / 0.04 \mathrm{M} \mathrm{I}_{2}$ (blue triangles) following $\sim 100 \mathrm{fs}$ excitation at $530 \mathrm{~nm}$; corresponding data acquired on $\mathrm{ZrO}_{2}$-based films are shown in the insets. The solid lines represent fits to exponential kinetic models. See text for further details.

consistent with observations made by Hagfeldt and co-workers, who noted no significant differences in injection kinetics for sensitized films measured in air versus those in contact with solutions that contained $\mathrm{LiI} / \mathrm{I}_{2} \cdot{ }^{23}$ The differences in injection kinetics by themselves (Figures 1, 2, S1 and S2) can not fully account for the 5-fold decrease in short-circuit current density observed when the electrolyte was changed from $\mathrm{LiI} / \mathrm{I}_{2}$ to $[(\mathrm{n}-$ $\left.\left.\mathrm{C}_{4} \mathrm{H}_{9}\right)_{4} \mathrm{~N}\right] \mathrm{I} / \mathrm{I}_{2}$, indicating that changes in other processes must also be occurring when the electrolyte is varied.

\section{Summary and Conclusions}

A number of components are required for a dye-sensitized solar cell to fully function. One of the most critical is a redoxactive shuttle, which in its reduced form can act as an electron donor for the oxidized sensitizer, thus regenerating the original ground-state of the chromophore. Subsequent reduction of the oxidized form of the reagent at the counterelectrode effectively completes the circuit. It is well-known that the $\mathrm{I}_{3}^{-} / \mathrm{I}^{-}$couple, which is created upon combination of an iodide salt with $\mathrm{I}_{2}$ in solution, has yielded $\mathrm{TiO}_{2}$-based dye sensitized solar cells with the highest overall efficiencies, particularly when the system is used in conjunction with ruthenium polypyridyl-based sensitizers. The practice of omitting the colored $\mathrm{I}_{3}{ }^{-}$component from the supporting electrolyte, and replacing it with nonredox active species such as $\mathrm{ClO}_{4}{ }^{-}$, for example, when carrying out timeresolved studies of the electron transfer dynamics of these cells 
is generally done out of convenience, due the high optical

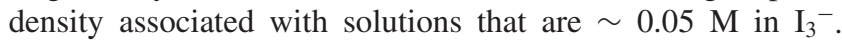
However, recent work suggesting that $\mathrm{I}^{-}$can quench the excitedstate of certain sensitizers, ${ }^{24,25}$ a process that would have a significant impact on the overall injection yield and therefore on the maximum current density, compelled us to consider whether the injection dynamics observed in the absence of the $\mathrm{I}_{3}{ }^{-} / \mathrm{I}^{-}$redox couple were reflective of processes occurring in the functional device.

The origin of the change in injection dynamics on going from $\left[\left(\mathrm{n}-\mathrm{C}_{4} \mathrm{H}_{9}\right)_{4} \mathrm{~N}\right]\left(\mathrm{ClO}_{4}\right)$ to $\left[\left(\mathrm{n}-\mathrm{C}_{4} \mathrm{H}_{9}\right)_{4} \mathrm{~N}\right] \mathrm{I} / \mathrm{I}_{2}$ is not clear. More work is needed to determine whether the sensitivity of the injection dynamics to the presence of the $\mathrm{I}^{-}$redox component is specific to the use of $\left(\mathrm{n}-\mathrm{C}_{4} \mathrm{H}_{9}\right)_{4} \mathrm{~N}^{+}$as a counterion in the supporting electrolyte, or is reflective of a more general phenomenon. Although several factors contribute to the drop in photocurrent upon shifting from $\mathrm{Li}^{+}$to $\left(\mathrm{n}-\mathrm{C}_{4} \mathrm{H}_{9}\right)_{4} \mathrm{~N}^{+},{ }^{15,17}$ the loss of the picosecond component in the overall injection process, while not the major factor, is certainly one of them. These results serve to underscore the importance of measuring the kinetics for this class of photovoltaics under the same conditions used for the acquisition of steady-state data if meaningful correlations with the performance characteristics of dye-sensitized photovoltaics are to be obtained.

Acknowledgment. Research was in part carried out at the Molecular Materials Research Center of the Beckman Institute of the California Institute of Technology. This work was supported by the Chemical Sciences, Geosciences, and Biosciences Division, Office of Basic Energy Science, U.S. Department of Energy Grants DE-FG02-03ER15483 (N.S.L.) and DE-FG02-01ER15282 (J.K.M.).

Supporting Information Available: Time-resolved differential absorption data for $\mathrm{N} 3$-sensitized $\mathrm{TiO}_{2}$ films in contact with $\left[\left(\mathrm{n}-\mathrm{C}_{4} \mathrm{H}_{9}\right)_{4} \mathrm{~N}\right] \mathrm{I}$ and LiI electrolytes in the presence and absence of added $\mathrm{I}_{2}$ (Figures $\mathrm{S} 1$ and $\mathrm{S} 2$ ). This material is available free of charge via the Internet at http://pubs.acs.org.

\section{References and Notes}

(1) O'Regan, B.; Grätzel, M. Nature 1991, 353, 737-740.

(2) Grätzel, M. Inorg. Chem. 2005, 44, 6841-6851.

(3) Frank, A. J.; Kopidakis, N.; van de Lagemaat, J. Coord. Chem. Rev. 2004, 248, 1165-1179.
(4) Nazeeruddin, M. K.; Zakeeruddin, S. M.; Lagref, J. J.; Liska, P.; Comte, P.; Barolo, C.; Viscardi, G.; Schenk, K.; Grätzel, M. Coord. Chem. Rev. 2004, 248, 1317-1328.

(5) Watson, D.; Meyer, G. J. Annu. Rev. Phys. Chem. 2005, 56, 119156.

(6) Hannappel, T.; Burfeindt, B.; Storck, W.; Willig, F. J. Phys. Chem. B 1997, 101, 6799-6802.

(7) Benkö, G.; Myllyperkiö, P.; Pan, J.; Yartsev, A. P.; Sundström, V. J. Am. Chem. Soc. 2003, 125, 1118-1119.

(8) Kuciauskas, D.; Monat, J. E.; Villahermosa, R.; Gray, H. B.; Lewis, N. S.; McCusker, J. K. J. Phys. Chem. B 2002, 106, 9347-9358.

(9) Asbury, J. B.; Ellingson, R. J.; Ghosh, H. N.; Ferrere, S.; Nozik, A. J.; Lian, T. Q. J. Phys. Chem. B 1999, 103, 3110-3119.

(10) Benkö, G.; Kallioinen, J.; Myllyperkiö, P.; Trif, F.; KorppiTommola, J. E. I.; Yartsev, A. P.; Sundström, V. J. Phys. Chem. B 2004, 108, 2862-2867.

(11) Asbury, J. B.; Anderson, N. A.; Hao, E. C.; Ai, X.; Lian, T. Q. J. Phys. Chem. B 2003, 107, 7376-7386.

(12) Kallioinen, J.; Benkö, G.; Myllyperkiö, P.; Khriachtchev, L.; Skårman, B.; Wallenberg, R.; Tuomikoski, M.; Korppi-Tommola, J.; Sundström, V.; Yartsev, A. P. J. Phys. Chem. B 2004, 108, 6365-6373.

(13) Tachibana, Y.; Haque, S. A.; Mercer, I. P.; Moser, J. E.; Klug, D. R.; Durrant, J. R. J. Phys. Chem. B 2001, 105, 7424-7431.

(14) Tachibana, Y.; Haque, S. A.; Mercer, I. P.; Durrant, J. R.; Klug, D. R. J. Phys. Chem. B 2000, 104, 1198-1205.

(15) Katz, J. E.; Brunschwig, B. S.; Lewis, N. S. to be submitted.

(16) Juban, E. A.; McCusker, J. K. J. Am. Chem. Soc. 2005, 127, 68576865

(17) Katz, J. E.; Smeigh, A. L.; McCusker, J. K.; Brunschwig, B. S.; Lewis, N. S. to be submitted.

(18) Harris, L. A.; Wilson, R. H. Annu. Rev. Mater. Sci. 1978, 8, 99134.

(19) The lifetime of the ${ }^{3}$ MLCT state of N3 is $\sim 10$ ns. The transient absorption signal therefore will show no significant change in intensity over the 200 ps window depicted here.

(20) A number of groups have measured sub-100 fs injection dynamics for $\mathrm{N} 3$ as well as several other dyes when attached to $\mathrm{TiO}_{2}$. See refs 6-14 for examples.

(21) A more definitive way to probe electron injection in these systems is to monitor the formation of conduction-band electrons in the $\mathrm{TiO}_{2}$ film. Experiments along these lines are currently in development.

(22) Acetic acid was added to the electrolyte to provide a redox-inactive source of protons. The HAc increased, and stabilized, the $J_{\mathrm{sc}}$ of either (n$\left.\mathrm{C}_{4} \mathrm{H}_{9}\right)_{4} \mathrm{~N}^{+}$- or $\mathrm{Li}^{+}$-based cells, resulting in internal quantum yields approaching unity. Conversely, the absence of acetic acid in the $\mathrm{Li}^{+}$-based cells results in a significant drop in photocurrent.

(23) Bauer, C.; Boschloo, G.; Mukhtar, E.; Hagfeldt, A. J. Phys. Chem. B 2002, 106, 12693-12704.

(24) Marton, A.; Clark, C. C.; Srinivasan, R.; Freundlich, R. E.; Sarjeant, A. A. N.; Meyer, G. J. Inorg. Chem. 2006, 45, 362-369.

(25) Clark, C. C.; Marton, A.; Srinivasan, R.; Sarjeant, A. A. N.; Meyer, G. J. Inorg. Chem. 2006, 45, 4728-4734.

JP803402X 